\title{
Perbedaan Zona Hambat Terhadap Jamur Malassezia furfur Antara Pemberian Ekstrak Umbi Bawang Putih (Allium sativum Linn) Dengan Ekstrak Kulit Umbi Bawang Putih (Allium sativum Linn)
}

\author{
Diah Ariana \\ Prodi D3 Teknologi Laboratorium Medik, FIK, Universitas Muhammadiyah Surabaya \\ diahariana0101@gmail.com
}

Tanggal Submit: 18 April 2018

Tanggal Review: 18 Mei 2018

Tanggal Publish Online:

23 Mei 2018

\section{ABSTRACT}

Tinea versicolor or pitiriasis versicolor is a skin disorder caused by Malassezia furfur infection which is a fungal infection on the skin of the chronic surface. Clinical features is in the form of fine spots that colored white to brown black, this infection is also called a skin fungus with blotches. Treatment of Tinea versicolor can use chemical or traditional medicine. Chemical treatments such as creams or ointments cause sticky taste, while one of the traditional medicine is the bulb and skin of the garlic bulb (Allium sativum Linn) containing allicin substances that are efficacious as an anti-fungal.

This research is an experimental research with the aim to know the difference of inhibition zone to Malessezia furfur fungus. There are 3 treatments with 9 repetitions. The extraction method used is the soxhlet method. Anti-fungal activity test was done by using rating method, Saboroud Dextrose Agar (SDA) media which has been inoculated with suspension of Malassezia furfur with concentration $1.5 \times 108 \mathrm{CFU} / \mathrm{ml}$ (Mc Farland standard).

Result of data analysis obtained by ANOVA $p=0,000<$ $\alpha=0,05$, that there is difference of inhibition zone from treatment of garlic bulb extract and skin of garlic bulb (Allium sativum Linn). It is indicated that there is effect of giving garlic bulb extract (Allium sativum Linn) and garlic bulb skin (Allium sativum Linn) to Malassezia furfur fungus. Further tests were performed to compare mean treatment i.e. HSD test. It was obtained sig (p) 0,016> $>0,05$ which means bulb extract and garlic bulb skin (Allium sativum Linn) have different effect.

Keywords: Tinea versicolor, Malassezia furfur, garlic bulb.

\section{PENDAHULUAN}

Jamur merupakan organ penyakit yang mudah terjadi terutama di negara-negara tropis, salah satunya yaitu negara Indonesia. Penyakit kulit yang disebabkan oleh jamur ini dikarenakan kondisi kulit yang mudah berkeringat, lembab, kebersihan diri yang tidak terjaga dan pengetahuan yang kurang sempurna tentang kesehatan, merupakan salah satu faktor penyebab pertumbuhan jamur kulit. 


Iklim tropis sangat furfur dan kemudian pada tahun

mendukung perkembangan infeksi 1889 oleh Baillon diberi nama jamur di Indonesia terutama terjadi karena udara lembab, tingkat kesehatan yang kurang baik, sanitasi dan pola hidup sehat kurang menjadi perhatian karena lingkungan padat penduduk atau sosial ekonomi yang rendah (Isselbacher et al., 1999 dalam Suryaningrum 2011).

Salah satu penyakit yang disebabkan jamur yang menyerang kulit adalah Pityriasis versicolor. Penyakit Pityriasis versicolor ini dikenal pertama kali sebagai penyakit jamur pada tahun 1846 oleh Eichsted. Secara umum penyakit ini dikenal sebagai penyakit panu. Pityriasis versicolor disebabkan oleh Malassezia furfur. Pityriasis versicolor adalah suatu penyakit jamur kulit yang kronik dan asimptomatik serta ditandai dengan bercak putih sampai coklat yang bersisik. Kelainan ini umumnya menyerang badan dan kadangkadang terlihat di ketiak, sela paha, tungkai atas, leher, muka, dan kulit kepala (Siregar, 2004).

Robin pada tahun 1853 memberi nama jamur penyebab penyakit ini dengan Microsporum Malassezia furfur (Partogi, 2008). Malassezia furfur sesunnguhnya merupakan bagian dari salah satu flora normal (Behrman, 2000).

$$
\text { Pada tahun 2008-2010 }
$$
Irmadita dan Sunarso melakukan penelitian secara retrospektif pada pasien mikosis superfisialis di Divisi Mikologi Unit Rawat Jalan (URJ) Kulit dan Kelamin RSUD Dr. Soetomo Surabaya. Dermatofitosis merupakan jenis mikosis superfisialis yang terbanyak diderita, yaitu berturut-turut 59,5\% (2008), 56,3\% (2009) dan 52,9\% (2010), dan infeksi Malassezia sebesar 31,6\% (2008), $34,1 \%$ (2009) dan 34,4\% (2010).

Obat antifungi yang dibuktikan pada kulit mempunyai kemampuan untuk menghambat pertumbuhan jamur dengan diikuti kecepatan pengelupasan kulit (Isselbacher et al., 1999 dalam Suryaningrum 2011). Menurut Hapson dan Rahmawati (2008) resistensi fungi terhadap obat diakibatkan pemakaian obat yang terus menerus, seperti pengobatan dosis tinggi waktu singkat, intermitten, dan dosis rendah jangka 
lama. Selain ini Obat - obat untuk mengobati jamur yang dijual di apotek atau toko obat topikal seperti krim adalah reaksi alergi seperti kemerahan pada kulit kepala atau kulit tubuh, bengkak, kulit kuring, rambut rontok, dan gatal-gatal.

Secara tradisional laos, jahe, dan bawang putih digunakan oleh sebagian masyarakat untuk mengobati gatal-gatal di kulit yang sering dikenal panu. Bahan-bahan tersebut dipakai dengan cara digosokkan pada daerah kulit yang gatal.

Kandungan kimia bawang putih antara lain: aliin, allisin, ajoene, alilpropil disulfida, dialil trisulfida, s-alilsistein, vinildithiine, s-alilmerkaptosistein, enzim-enzim antara lain: alinase, peroksidase, mirosinase, asam amino dan glikosidanya (arginin), selenium, germanium, tellurium (Prapti, Pramono, dan Widiyastuti, 2013). Sebuah sampel dari allicin murni terbukti antijamur (Hughes dan Lawson, 1991). Bawang putih mampu menghambat pertumbuhan Candida albicans secara efektif (Sari, 2014).
Bawang putih menghasilkan limbah berupa kulit. Menurut penelitian (Ichikawa et al., 2003) ekstrak kulit bawang putih menunjukkan aktivitas antioksidan. Antioksidan merupakan salah satu cara dalam menghambat dan mencegah reaksi radikal bebas (Olajire dan Azeez, 2011).

Dengan demikian, umbi bawang putih dan kulit bawang putih yang merupakan limbah, memiliki potensi untuk dimanfaatkan sebagai anti jamur. Oleh sebab itu peneliti ini bertujuan untuk mengetahui potensi kulit bawang putih dalam menghambat pertumbuhan jamur kulit khususnya Malassezia furfur.

\section{METODE PENELITIAN}

Jenis penelitian ini menggunakan rancangan penelitian eksperimental yaitu untuk mengetahui perbedaan pemberian ekstrak umbi bawang putih (Allium sativum Linn) dan kulit umbi bawang putih (Allium sativum Linn) terhadap zona hambat jamur Malessezia furfur. 


\section{Variabel Penelitian}

Variabel penelitian ini adalah:

1. Variabel bebas : Bahan ekstrak tanaman umbi bawang putih (Allium sativum Linn) dengan ekstrak kulit umbi bawang putih (Allium sativum Linn).

2. Variabel terikat : Zona hambat Jamur Malessezia furfur.

3. Variabel kontrol : Lama sterilisasi, lama inkubasi, suhu, volume suspensi.

\section{Tehnik Pengumpulan Data}

Data diperoleh dengan uji Laboratorium dengan mengamati perbedaan zona hambat jamur Malassezia furfur pada pemberian ekstrak umbi bawang putih (Allium sativum Linn) dengan kulit umbi bawang putih (Allium sativum Linn) dengan menggunakan metode difusi sumuran.

\section{Prosedur Penelitian}

\section{a. Pembuatan Ekstrak Umbi Bawang Putih (Allium sativum Linn) \\ Alat yang digunakan :}

Mortal, labu ekstraksi, soxhlet, statif, penangas air, hotplate, selang plastik, kondensor, termometer.

Bahan yang digunakan : Tumbukan umbi bawang putih (Allium sativum
Linn) tidak busuk dan segar, etanol $96 \%$

Prosedur kerja :

1. Umbi bawang putih (Allium sativum Linn) yang diambil adalah tidak busuk dann segar.

2. Mengupas kulit umbi bawang putih (Allium sativum Linn).

3. Memotong umbi bawang putih (Allium sativum Linn) hingga kurang lebih 1-2 cm dan letakkan dalam wadah.

4. Memasukkan dalam mortal dan menumbuk dengan kasar.

5. Menimbang 100 gram umbi bawang putih (Allium sativum Linn) yang sudah ditumbuk.

6. Menyiapkan rangkaian alat ekstraksi soxhlet.

7. Membungkus bahan ekstraksi dengan kertas saring dan memasukkannya ke dalam soxhlet.

8. Memasukkan $400 \mathrm{ml}$ etanol 96\% kedalam labu ektraksi.

9. Memanaskan pelarut menggunakan waterbath dengan suhu $70-78^{0} \mathrm{C}$.

10. Memperhatikan siklus ekstraksi, ekstraksi berakhir setelah siklus pelarut menjadi jernih. 
11. Ekstrak umbi bawang putih (Allium sativum Linn) siap digunakan (Nurhasanah dkk, 2017).

b. Penanaman

Malassezia furfur pada Media Saboroud Dextrose Agar (SDA)

Alat yang digunakan : Pipet ukur steril, filler atau push ball.

Bahan yang digunakan :bSuspensi jamur Malassezia furfur, spirtus.

Prosedur kerja :

1. Mengambil suspensi jamur Malassezia furfur dengan menggunakan pipet ukur steril, penanaman menggunakan api spirtus, lalu menggesekkan dengan cotton swab pada permukaan media Saboroud Dextrose Agar (SDA) dan menambahkan olive oil.

2. Inkubasi pada inkubator $37^{\circ} \mathrm{C}$ selama $5 \times 24$ jam.

3. Mengamati pertumbuhan jamur Malassezia furfur yang tumbuh pada media Saboroud Dextrose Agar (SDA).

c. Perlakuan Penghambatan Ekstrak bawang putih (Allium sativum Linn) dan Kulit Umbi Bawang Putih (Allium sativum Linn) tehadap Pertumbuhan Jamur Malassezia furfur

Alat yang digunakan: Mikropipet, ring.

Bahan yang digunakan: Ekstrak umbi bawang putih (Allium sativum Linn), ekstrak kulit umbi bawang putih (Allium sativum Linn), spirtus.

Prosedur :

1. Memasukkan ring pada media Saboroud Dextrose Agar (SDA) pada media yang sudah diinokulasi jamur Malassezia furfur.

2. Memasukkan ekstrak umbi bawang putih (Allium sativum Linn) dengan kulit umbi bawang putih (Allium sativum Linn) pada masingmasing ring.

3. Melakukan hal tersebut pada replikasi (Panduan Praktikum Mikrobiologi, 2016)

\section{HASIL DAN PEMBAHASAN}

Berdasarkan hasil penelitian perbedaan zona hambat jamur Malessezia furfur dengan pemberian ekstrak umbi bawang putih (Allium sativum Linn) dengan kulit umbi bawang putih (Allium sativum Linn) di Laboratorium Mikrobiologi Prodi D3 Analis Kesehatan Fakultas Ilmu Kesehatan Universitas Muhammadiyah Surabaya diperoleh hasil sebagai berikut : 
Tabel 1. Hasil rata-rata dan SD perbedaan zona hambat jamur Malessezia furfur dengan pemberian ekstrak umbi bawang putih (Allium sativum Linn) dengan kulit umbi bawang putih (Allium sativum Linn)

\begin{tabular}{|c|l|l|l|}
\hline \multirow{2}{*}{$\begin{array}{c}\text { Repli } \\
\text { kasi }\end{array}$} & \multicolumn{3}{|l|}{ Zona hambat diameter (mm) } \\
\cline { 2 - 4 } & $\begin{array}{l}\text { Tanpa } \\
\text { pembe } \\
\text { rian } \\
\text { ekstrak }\end{array}$ & $\begin{array}{l}\text { Pemberian } \\
\text { ekstrak } \\
\text { umbi } \\
\text { bawang } \\
\text { putih } \\
\text { (Allium } \\
\text { sativum } \\
\text { Linn) } \\
100 \%\end{array}$ & $\begin{array}{l}\text { Pemberian } \\
\text { ekstrak } \\
\text { kulit umbi } \\
\text { bawang } \\
\text { putih } \\
\text { (Allium } \\
\text { sativum } \\
\text { Linn) } \\
100 \%\end{array}$ \\
\hline 1. & 0 & 10 & 7 \\
\hline 2. & 0 & 8 & 8 \\
\hline 3. & 0 & 9 & 7 \\
\hline 4. & 0 & 11 & 9 \\
\hline 5. & 0 & 8 & 10 \\
\hline 6. & 0 & 8 & 7 \\
\hline 7. & 0 & 10 & 8 \\
\hline 8. & 0 & 11 & 9 \\
\hline 9. & 0 & 10 & 8 \\
\hline Total & 0 & 85 & 73 \\
\hline $\begin{array}{l}\text { Rata- } \\
\text { rata }\end{array}$ & 0 & 9,44 & 8,11 \\
\hline SD & 0 & 1,236033 & 1,054093 \\
\hline
\end{tabular}

Dari tabel 4.1.1 diatas dapat dilihat terdapat perbedaan zona hambat jamur Malassezia furfur antara pemberian ekstrak umbi bawang putih (Allium sativum Linn) dengan ekstrak kulit umbi bawang putih (Allium sativum Linn).

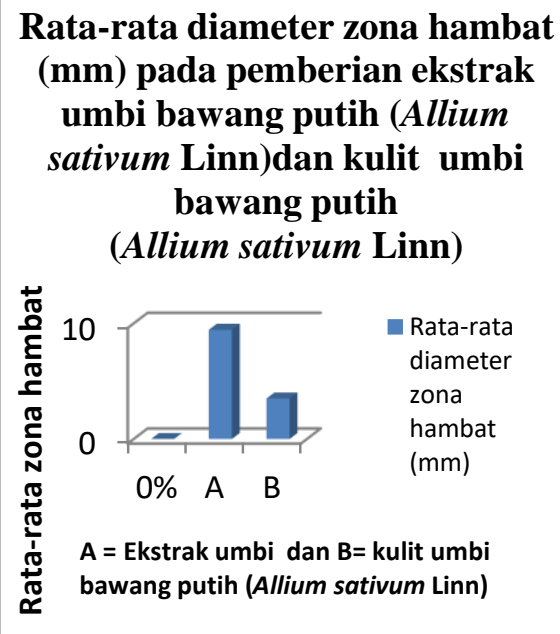

Gambar 1. Diagram batang rata-rata zona hambat terhadap jamur Malessezia furfur antara pemberian ekstrak umbi bawang putih (Allium sativum Linn) dan kulit umbi bawang putih (Allium sativum Linn).

Keterangan :

A : Ekstrak Umbi Bawang Putih (Allium sativum Linn)

B : Ekstrak Kulit Umbi Bawang Putih (Allium sativum Linn)

\section{Analisis data}

Dari uji normalitas menggunakan Kolmogorov-Smirnov test didapatkan hasil signifikan $(\mathrm{p})=$ 0,191 lebih besar dari $\alpha 0.05$ yang berarti bahwa data yang diperoleh ber distribusi normal.

Berdasarkan tabel 4.1.2 diperoleh nilai $\operatorname{sig}(\mathrm{p})=0,000$, dimana lebih kecil dari nilai $\alpha=0,05$ sehingga Ho ditolak. Maka dapat disimpulkan bahwa ada perbedaan zona hambat dari perlakuan pemberian ekstrak umbi bawang putih (Allium sativum Linn) dan kulit umbi bawang putih (Allium sativum 
Linn). Hal ini berarti ada pengaruh pemberian ekstrak umbi bawang putih (Allium sativum Linn) dan kulit umbi bawang putih (Allium sativum Linn) terhadap jamur Malassezia furfur.

Dari tabel 2.6. Diperoleh nilai (sig (p) $0,016>\alpha 0,05)$ yang berarti ekstrak umbi bawang putih (Allium sativum Linn) dan kulit umbi bawang putih (Allium sativum Linn) memiliki pengaruh yang berbeda. Ekstrak umbi bawang putih (Allium sativum Linn) terdapat rata-rata zona hambat 9,44 mm dan ekstrak kulit umbi bawang putih (Allium sativum Linn) lebih kecil, dengan rata-rata zona hambat $8,11 \mathrm{~mm}$.

Adanya pengaruh pemberian ekstrak umbi dan kulit umbi bawang putih (Allium sativum Linn) terhadap Malassezia furfur bahwa umbi dan kulit umbi bawang putih (Allium sativum Linn) mengandung senyawa allicin. Menurut penelitian Dewi (2016) senyawa allicin dapat mengahambat aktivitas enzim fungi yang menyebabkan infeksi dan gangguan metabolisme, yaitu enzim sistein proteinase dan enzim alkohol dehidrogenase. Senyawa allicin memiliki kemampuan antijamur dengan bergabung bersama protein dan mengubah struktur yang mudah dicerna. Kemampuan bergabung dengan protein itulah yang akan mendukung daya antibiotik, karena allicin menyerang protein mikroba dan akhirnya membunuh mikroba tersebut (Kulsum, 2014). Allicin juga menunjukkan aktivitas antimikroba dengan menghambat sistesis ribonucleic acid (RNA) dengan cepat dan menyeluruh. Selain itu, sintesis deoxyribonucleic acid (DNA) dan protein juga dihambat secara partial (Feldberg et al., 1988).

Selain allicin kulit umbi bawang putih (Allium sativum Linn) mempunyai aktivitas antioksidan yang dapat merusak sel Malassezia furfur (Olajire dan Azeez, 2011). Sedangkan menurut Barnes (2007) kandungan senyawa kimia yang terdapat pada bawang putih yang memiliki aktivitas jamur antijamur adalah allicin.

$$
\text { Berdasarkan pembahasan }
$$
diatas menunjukkan bahwa ekstrak umbi dan kulit umbi bawang putih (Allium sativum Linn) berpengaruh terhadap pertumbuhan jamur Malassezia furfur dengan ditunjukkan rata-rata zona hambat 
yang lebih luas dar ekstrak umbi bawang putih (Allium sativum Linn) yaitu 9,44 $\mathrm{mm}$ sedangkan pada ekstrak kulit umbi bawang putih (Allium sativum Linn) yaitu 8,11 mm. Esktrak umbi bawang putih (Allium sativum Linn) dan kulit umbi bawang putih (Allium sativum Linn) bersifat anti jamur yaitu menghambat pertumbuhan jamur Malassezia furfur.

\section{KESIMPULAN}

Dari hasil penelitian yang
dilakukan yaitu perbedaan zona
hambat jamur Malessezia furfur
dengan pemberian ekstrak umbi
bawang putih (Allium sativum Linn)
dengan kulit umbi bawang putih (Allium sativum Linn) terhadap pertumbuhan jamur Malassezia furfur dapat diambil kesimpulan : Terdapat perbedaan zona hambat zona hambat terhadap jamur Malessezia furfur antara pemberian ekstrak umbi bawang putih (Allium sativum Linn) dengan kulit umbi bawang putih (Allium sativum Linn).

\section{DAFTAR PUSTAKA}

Adillah, Gabriella Noor. 2012. Pengaruh Perasan Jeruk Nipis (Citrus aurantifolia) Terhadap Pertumbuhan Jamur Malassezia furfur Secara Invitro. Jurusan Analis Kesehatan Poltekkes Kemenkes: Surabaya.

Anonim.2013.Alatalatlaboratorium.h ttp://alatalatlaboratorium.com/ LaboratoriumMikrobiologi/wpcontent/uploads/2013/08/Petun juk-Penggunaan-SDA.jpg (Diakses tanggal 18 Juli 2017).

Anonim.2010.PitiriasisVersicolor(P anu).http://calvariatmc.blogspo t.com/2010/12/pitiriasisversicolor-panu.html (Diakses tanggal 24 Juni 2017).

Barnes, J., Anderson, L.A and Phillipson, J.D. 2007. Herbal Medicines, $3^{\text {th }}$ ed. London: Pharmaceutical Press.

Behrman, Richard E; Robert M Kliegman; Ann M Arvin; editor edisi bahasa Indonesia, A. Samik Wahab -Ed 15-. 2000. Ilmu Kesehatan Anak Nelson Vol. 3. Jakarta: EGC.

Block, E. And S. Ahmad. 1984. (EZ)-Ajoene: a potent antithrombotic agent from garlic. J. Am. Chem.soc. 106:8295-8296.

Budimulja, U. 2010. Mikosis. In: Djuanda A, Hamzah M, Aisah S, editors. Ilmu Penyakit Kulit Dan Kelamin Ed 6. Jakarta: Fakultas Kedokteran Universitas Indonesia. 
Dewi \& Warganegara. 2016. Manfaat bawang putih (Allium sativum Linn) pada pengobatan infeksi fungal Tinea versicolor (Panu). Vol.5, no 1, hal 33-37.

Donald, I. Patt \& Gail, R. Patt. 1975. An Introduction to Modern Genetics. Philippines: Addison-Wesley. P179.

Fardiaz,S. 1989. Mirobiologi Pangan. IPB: PAU Pangan dan Gizi. Bogor.

Feldberg, Ross., Chang, S., Kotik, A., Nadler, M., Neuwirth, Z., Sundstrom, D.,

Fesseden, R.J. dan J.S. Fesseden. 1986. Kimia Organik. Jakarta: Erlangga.

Gandahusada, Sutanto; Is Suhariah Ismid; Pudji K. Sjarifuddin; Saleha Sungkar. 2013. Parasitologi Kedokteran Ed.4. Jakarta: Fakultas Kedokteran Universitas Indonesia.

Gritter, R. J., M. James dan E. S. Arthur. 1991. Pengantar kromatografi. Bandung: Institut Teknologi Bandung.

Harborne, J., 1987. Metode Fitokimia: Penuntun Cara Modern Menganalisis

Tumbuhan. Cetakan kedua. Penerjemah: Padmawinata, K. Dan I. Soediro. Bandung: Penerbit ITB.

Hargono, J. 1986. Efek samping obat dari bahan alam lebih kecil daripada efek samping obat kimia murni. Cermin Dunia Farmasi.
Hirasawa, M., "et al”, 1999, The Kinds of Antibacterial Subtances from Lentinus adobes Singshitake an Edible Mushroom. International Journal of Antibacterial Agents 11, 1561-157.

Hughes, B.G dkk. 1991. Antimicrobial Effect of Allium sativum L. (garlic), Allium ampeloprasum L. (elephant garlic), and Allium cepa L. (onion), Garlic Compounds and Commercial Garlic Supplement Product. Phytother. Res.5: 154-158.

Hopkins, W.G.1999. Introduction to Plant Physiology, 2nd edition, New York: John Wiley and Sons, Inc.

Ichikawa, Makoto dkk. 2003. Journal of Agricurtural and Food Chemistry.

Irianto, Koes. 2014. Bakteriologi Medis, Mikologi Medis, Dan Virologi Medis (Medical Bacteriology, Medica Micology, and Medical Virology). Bandung. Alfabeta CV.

Khairani, A. 2014. Bawang Putih Raja Tanaman Kedokteran. Surabaya. Alfasyam Publishing.

Lutfiyanti, R. Ma'ruf, W.F dan Dewi, E.N. 2012. Aktivitas Antijamur Senyawa Bioaktif Ekstrak Gellidium latifolium terhadap Candida albicans. Jurnal Pengolahan dan Bioteknologi Hasil Pperikanan. 
Madani, Fattah. 2000. Infeksi jamur kulit. In: Marwali $\mathrm{H}$, editor. Ilmu Penyakit Kulit. Jakarta: Hipokrates; 2000.

Nurhasanah dkk. 2017. Ekstraksi Senyawa Bioaktif Dari Rimpang Curcuma Mangga Menggunakan Pelarut Ramah Lingkungan Natural Deep Eutectic Solvent (NADES). Fakultas Teknologi Industri Institut Teknologi Sepuluh Nopember Surabaya.

Olajire, A.A. and Azeez, L. (2011). Total antioxidant activity, phenolic, flavonnoid and ascorbic acid contents of Nigerian vegetables. African Journal of Food Science and Technology 2(2):022-029.

Panduan Praktikum Mikrobiologi. 2016. Fakultas Farmasi Universitas Sanata Dharma.

Rahmad, Taufiq. 2014. Budidaya Jamur Menggiurkan. Yogykarta. Indopublika.

Rahman, Arief. 2011. Uji Banding Efektivitas Allium Sativum (Bawang Putih) 2\% Dengan Ketokonazol 2\% Secara In Vitro Terhadap Pertumbuhan Malassezia Furfur Pada Pityriasis Versicolor. Jurnal ilmu-ilmu kesehatan Surya Medika Vol 7. No 1.

Rahmawati, Reny. 2012. Keampuhan Bawang Putih Tunggal (Bawang Lanang). Yogyakarta. Pustaka Baru Press.
Rastagno, Mauricio, and Juliana Prado. 2003. Natural Product Extraction. RSC Publishing.

Rieska, Raniyanti Alfiah. 2015. Efektivitas Ekstrak Metanol Daun Sembung Rambat (Mikania micrantha Kunth) Terhadap Pertumbuhan Jamur Candida albicans. Jurnal Protobiont Vol.4.

Setiyani, Alis. 2010. Uji Aktivitas Antijamur $\alpha$-Mangostin Hasil Isolasi Kulit Buah Manggis Terhadap Malassezia sp. Fakultas Farmasi Universitas Muhammadiyah: Surakarta.

Siregar, R.S. 2004. Penyakit Jamur Kulit Ed.2. Jakarta:EGC.

Subhisna, S. 2005. Antifungal Activities of a Steroid from Pallavicinia lylii a Liverwort. Tropical Botanic Garden and Research Institute.

Supranto J. Teknik sampling untuk survey dan eksperimen. Jakarta: PT Rineka Cipta; 2000.

Suryaningrum, Esti rahmawati, 2011. Efek antifungi perasan kulit jeruk (Citrus hystrix) terhadap pertumbuhan Trichophyton mentagrophytes secara in vitro. Fakultas kedokteran universitas sebelas maret surakarta.

Susilo, Kartika. 2011. Petunjuk praktis bertanam bawang. Jakarta Selatan. PT Agromedia Pustaka. 
Tiwari, Amit Kumar; Rohit Kumar Mishra; Awadhesh Kumar; Shalu Srivastava; Anupam Dikshit; Anand Pandey; K Bajaj. 2011. A Comparative Novel Method Of Antifungal Susceptibility For Malassezia furfur And Modification of Culture Medium By Adding Lipid Supplement. University of Allahabad: India.
Waluyo, L. 2007. Mikrobiologi Umum. UMM Press. Malang.

Watson, R.R dan Preedy, V.R. 2007. Bioactive Foods in Promoting Health: Probiotics and Prebiotics. USA: Academic Press.

Wibowo, Singgih. 2003. Budi Daya Bawang. Jakarta. PT Penebar Swadaya. 